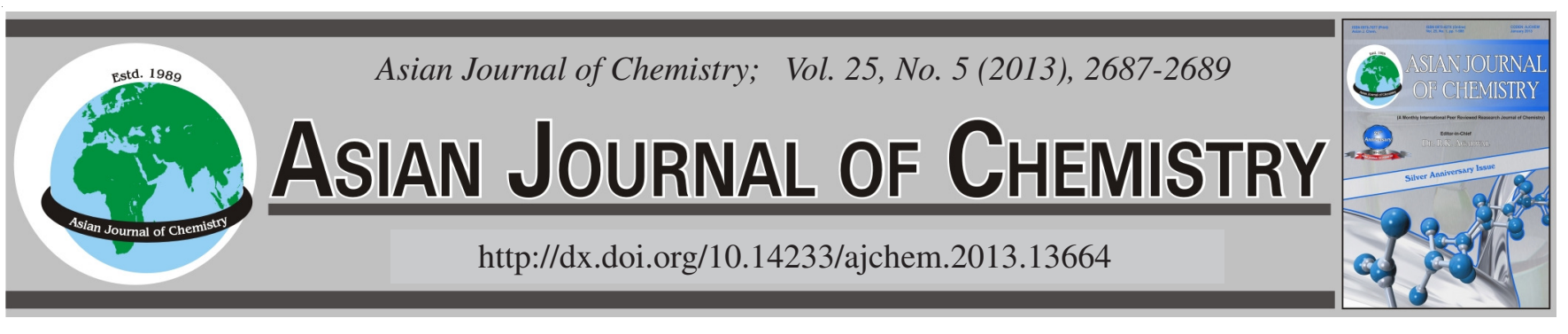

\title{
Correlative Evaluation Between Nickel Ion Concentrations Doped in Some River Side Water Bodies of NënShkodra Lowland and Root Growth of Allium cepa (L.)
}

\author{
Anila Mesi (Dizdari) ${ }^{*}$, Ditika Kopliku, Anila Neziri and Suzana Golemi
}

Department of Biology and Chemistry, University of Shkodra "Luigj Gurakuqi", Shkodër, Albania

*Corresponding author: Fax: +355 22243747; Tel: +355 683986248; E-mail: aniladizdari@yahoo.it

In this investigation, the Allium test was applied to detect the inhibition of root growth by six nickel concentrations, doped in four riverside water sampes from NënShkodra lowland. Significant growth inhibition started at $0.5-1 \times 10^{-4} \mathrm{M} \mathrm{Ni}^{2+}$ concentrations in all samples compared to drinking water control. Nickel concentrations higher than $5 \times 10^{-4} \mathrm{M}$ did not demonstrate any cumulative inhibitory effect. Mean root length and toxic effective concentrations values indicated the same decreasing amount and toxicity range of $\mathrm{Ni}^{2+}$ loaded samples: Bahçellek > Zues > Oblikë e Madhe > Obot i Vjetër > control. Based on $\mathrm{EC}_{50}$ values, nickel concentration in drinking water should be decreased by a factor of: $3.9,2.7,1.5$ and 1.45 to obtain the same root growth inhibition effect corresponding to: Bahçellek, Zues, Oblikë and Obot. This biotest could screen nickel quantal and toxic tendency of analyzed natural waters.

Key Words: Phytotoxicity, Allium test, $\mathbf{E C}_{50}$, Nickel, Water pollution.

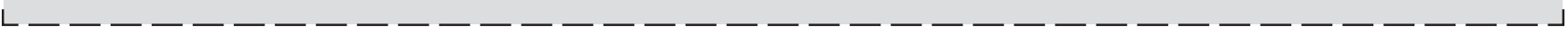

\section{INTRODUCTION}

The environment contamination by nickel consists in a recent problematic concern ${ }^{1-3}$. Nickel is released into the environment from human activities ${ }^{4}$ and natural processes. Metals as nickel are leached out by mining industry and carried downstream as water washes over the rock surface. Although metals can become mobile in neutral $\mathrm{pH}$ conditions, leaching is particularly accelerated in the low $\mathrm{pH}$ conditions such as are created by acid mine drainage, erosion and sedimentation. The free ion, or more generally, the labile fraction, is assumed to be the bio-available fraction of metals in water and responsible for observed toxicity ${ }^{5,6}$. In the absence of adequate prevention and control strategies, erosion of the exposed earth may carry substantial amounts of sediment into streams, rivers and lakes ${ }^{7,8}$.

Standard targeted chemical analyses do not provide information about the biological effects of pollutants that occur in concentrations too low to be determined analytically. In this context, toxicity tests employing microorganisms, plant and mammalian cells, have been used, alone or in combination with chemical analysis. The Allium test (A. cepa L.) is commonly used as a bioindicator of heavy metals phytotoxicity ${ }^{9,10}$. Recent reports ${ }^{11-15}$ of NënShkodra lowland water bodies (important agricultural area in north-west Albania) showed significant increase of heavy metals concentration in these water bodies and sediments (especially chromium and nickel) during the last years. In this paper the Allium test was used to detect the root length inhibition effect of different concentrations of nickel doped in some riverside water sampling points of NënShkodra lowland, because of nickel mine presence down streaming Drini river.

\section{EXPERIMENTAL}

Sampling was done during April-May 2010. Surface water was collected, using Van Dorm bottles, from Drini and Buna rivers at four different sampling sites (2-5). A sample of treated drinking water was obtained at site 1 , Dobraç (main Shkodra city's drinking water supply) used as control test. The natural sample sites were located as follows: site 2, Bahçellek bridge (Drini river), in the vicinity of Shkodra city; site 3, Zues (union point of Drini and Buna rivers), site 4, Oblikë e Madhe and site 5, Obot i Vjetër (Buna and Drini downstream of an agricultural area, extremely damaged from 2010 massive flooding).

Preliminary range of toxic Ni concentration finding: Concentrations between the highest concentration that inhibited root growth and the lowest concentration that rarely inhibited the root growth were assessed. As a result, six definitive concentrations of $\mathrm{Ni}\left(\mathrm{NO}_{3}\right)_{2}$ salt: $0.5 \times 10^{-4}, 1 \times 10^{-4}$, $2.5 \times 10^{-4}, 5 \times 10^{-4}, 10 \times 10^{-4}$ and $15 \times 10^{-4} \mathrm{M}$, were chosen from the range to establish the further full-scale chronic and acute toxicity test. 
Test samples preparation: To obtain the test solutions loaded with metallic ion, the treatment concentrations were prepared in laboratory, using as a solvent drinking and river waters taken from sampling sites. Unloaded drinking and natural water samples were tested and used as control samples, too.

Test procedure: Equal-sized bulbs of commercial onion (Allium cepa L.), were grown for four days in laboratory and root elongation test was done, second the method proposed by Fiskesjö ${ }^{9}$. The outer scales have been removed, leaving the ring of root primordia intact. All the experiments were set up in a completely randomized design with 12 test tubes and 3 replicates. Each series has been filled with unloaded and loaded solutions. Onion bulbs have been put on top of test tubes with the root primordia downward in the solution. The test procedure was performed in room temperature $\left(+20^{\circ} \mathrm{C}\right)$ with a natural light-dark regime and protected from direct sun light.

The toxicity of nickel was evaluated screening the root bundle length inhibition for 4 days. The length of each root bundle was measured from the outside of the test tube; a mean of root length $(\mathrm{MRL} \pm \mathrm{SD}$ ) for each sample was collected for the test report ( 5 water samples $\times 7$ different unloaded and loaded solutions $\times 36$ bulbs). All mean root length values have been compared with the respective mean root length of control tests, using $\chi^{2}$ test at $\mathrm{p}<0.05$ level of significance.

Determination of phytotoxicity levels: $\mathrm{EC}_{70}, \mathrm{EC}_{50}$ and $\mathrm{EC}_{30}$, (effective concentration of $\mathrm{Ni}$ salt, permitting respectively: 70, 50 and $30 \%$ root growth of the sample under study in relation to control growth) were used to determine and compare the tendency of nickel amount and phytotoxicity level in examined natural samples. $\mathrm{EC}_{70}, \mathrm{EC}_{50}$ and $\mathrm{EC}_{30}$ values were statistically evaluated by plotting mean root length values on line graphs. The power equations that had the maximum $\mathrm{R}^{2}$ values were selected to estimate the toxicity levels.

\section{RESULTS AND DISCUSSION}

The visible effect of nickel salt was stunted root growth in all samples in concentrations higher than $1 \times 10^{-4} \mathrm{M}$. The mean root length of loaded samples, estimated as a function of the doped metal concentrations, were expressed as a percentage of the respective mean root length of unloaded samples (Table-1). Mean root length value of unloaded Dobraç (3.81 $\mathrm{cm} \pm 0.57)$ sample resulted a linear growth aproximately 1 $\mathrm{cm} /$ day, in accordance with the respective values from the literature ${ }^{9,16,17}$, which means good chemical quality. That is the reason why a good quality of drinking water was used as a test control sample. There was concentration-dependent root growth: the detected growth inhibition came increasing with addition of nickel salt in all water samples (Table-1). The inhibition of root growth at $1 \times 10^{-4} \mathrm{Ni}$ concentration was statistically significant (at level 0.05) in samples of Bahçellek and Zues. In Dobraç, Oblikë e Madhe and Obot i Vjetër samples the significant inhibition started at $2.5 \times 10^{-4} \mathrm{M}$ salt concentration. Standard deviation values showed compatibility with the above results: SD decrease with increasing Ni concentration (Table-1).

Natural unloaded samples did not showed significant growth restriction. Mean root length results of Oblikë e Madhe (85\%) and Obot i Vjetër (87 \%) showed a good water quality, compared to control (Table-2). Concerning Bahçellek and Zues, the inhibition was insufficient to register a statistically significant difference to control (76 and $77 \%$ ), as a consequence these natural samples presented virtually normal growth and were considered nontoxic.

The different response in root length to the same Ni concentration in the rapid decrease region of the graph $\left(0.5 \times 10^{-4}\right.$ $\left.5 \times 10^{-4} \mathrm{M}\right)$ indicated the chronic toxicity range of samples: Bahçellek > Zues > Oblikë e Madhe > Obot i Vjetër > Dobraç. Root growth restriction was firstly detected in Bahçellek and Zues samples at $0.5 \times 10^{-4} \mathrm{M}(64$ and $65 \%)$ and after that in Oblikë e Madhe and Obot i Vjetër at $1 \times 10^{-4}$ M (64 and 67 $\%)$. In addition, these results evaluated the possible tolerance limit of nickel quantity $\left(<0.5 \times 10^{-4} \mathrm{M}\right)$ for normal root growth of $A$. сеpa, virtually doped by effluents in Drini and Buna rivers. Furthermore, no significant change of inhibition effect was detected at $\mathrm{Ni}^{2+}$ concentrations higher than $5 \times 10^{-4} \mathrm{M}$ in all the water samples (Table-2 and Fig. 1).

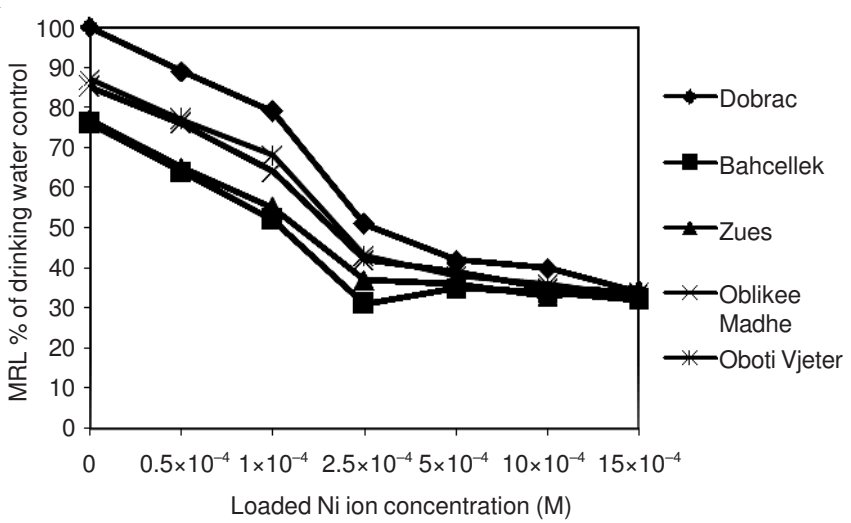

Fig. 1. Line graph of natural sample mean root length values expressed in percentage of control, as a function of loaded metal concentrations

TABLE-1

MEAN ROOT LENGTH VALUES (in $\mathrm{cm}$ ) COMPARISON BETWEEN UNLOADED AND LOADED SAMPLES

\begin{tabular}{|c|c|c|c|c|c|}
\hline \multirow{2}{*}{$\begin{array}{l}\text { Loaded } \mathrm{Ni}\left(\mathrm{NO}_{3}\right)_{2} \\
\text { concentration }(\mathrm{M})\end{array}$} & \multicolumn{5}{|c|}{ Samples mean root length [MRL $( \pm$ SD)] } \\
\hline & Dobraç & Bahçellek & Zues & O. e Madhe & O. i Vjetër \\
\hline 0 & $3.81 \pm 0.57$ & $2.85 \pm 0.42$ & $2.90 \pm 0.39$ & $3.23 \pm 0.55$ & $3.33 \pm 0.53$ \\
\hline $0.5 \times 10^{-4}$ & $3.38 \pm 0.45$ & $2.44 \pm 0.35$ & $2.48 \pm 0.35$ & $2.90 \pm 0.43$ & $2.93 \pm 0.41$ \\
\hline $1 \times 10^{-4}$ & $2.99 \pm 0.40$ & $1.98 \pm 0.30^{\mathrm{a}}$ & $2.10 \pm 0.34^{\mathrm{a}}$ & $2.45 \pm 0.38^{\mathrm{a}}$ & $2.60 \pm 0.37$ \\
\hline $2.5 \times 10^{-4}$ & $1.94 \pm 0.31^{\mathrm{a}}$ & $1.18 \pm 0.25^{\mathrm{a}}$ & $1.41 \pm 0.28^{\mathrm{a}}$ & $1.60 \pm 0.33^{\mathrm{a}}$ & $1.64 \pm 0.34^{\mathrm{a}}$ \\
\hline $5 \times 10^{-4}$ & $1.60 \pm 0.28^{\mathrm{a}}$ & $1.33 \pm 0.24^{\mathrm{a}}$ & $1.37 \pm 0.25^{\mathrm{a}}$ & $1.49 \pm 0.27^{\mathrm{a}}$ & $1.45 \pm 0.26^{\mathrm{a}}$ \\
\hline $10 \times 10^{-4}$ & $1.52 \pm 0.29^{\mathrm{a}}$ & $1.29 \pm 0.25^{\mathrm{a}}$ & $1.26 \pm 0.26^{\mathrm{a}}$ & $1.33 \pm 0.27^{\mathrm{a}}$ & $1.37 \pm 0.25^{\mathrm{a}}$ \\
\hline
\end{tabular}




\begin{tabular}{|c|c|c|c|c|c|}
\hline \multicolumn{6}{|c|}{$\begin{array}{c}\text { TABLE-2 } \\
\text { MEAN ROOT LENGTH }(\%) \text { OF DRINKING AND NATURAL } \\
\text { WATER SAMPLES IN EACH EXPERIMENTAL } \\
\mathrm{Ni}^{2+} \text { ION CONCENTRATION, COMPARED TO } \\
\text { DRINKING WATER CONTROL }\end{array}$} \\
\hline \multirow{2}{*}{$\begin{array}{c}\text { Loaded } \\
\mathrm{Ni}\left(\mathrm{NO}_{3}\right)_{2} \\
\text { concentration } \\
(\mathrm{M})\end{array}$} & \multicolumn{5}{|c|}{$\begin{array}{c}\text { Samples mean root length (\%) of drinking water } \\
\text { control }\end{array}$} \\
\hline & Dobraç & Bahçellek & Zues & $\begin{array}{c}\text { O. e } \\
\text { Madhe }\end{array}$ & $\begin{array}{c}\text { O. i } \\
\text { Vjetër }\end{array}$ \\
\hline 0 & 100 & 76 & 77 & 85 & 87 \\
\hline $0.5 \times 10^{-4}$ & 89 & 64 & 65 & 76 & 77 \\
\hline $1 \times 10^{-4}$ & 79 & 52 & 55 & 64 & 68 \\
\hline $2.5 \times 10^{-4}$ & 51 & 31 & 37 & 42 & 43 \\
\hline $5 \times 10^{-4}$ & 42 & 35 & 36 & 39 & 38 \\
\hline $10 \times 10^{-4}$ & 40 & 34 & 33 & 35 & 36 \\
\hline $15 \times 10^{-4}$ & 34 & 32 & 35 & 34 & 33 \\
\hline
\end{tabular}

Depending on $\mathrm{EC}_{70}$ and $\mathrm{EC}_{50}$ values (Table-3), the samples range resulted the same: Bahçellek < Zues < Oblikë e Madhe $<$ Obot i Vjetër < Dobraç, demonstrating compatibility with evaluated toxicity effect at mean root length. $\mathrm{EC}_{30}$ toxicity effect was quite similar in all samples, due to high Ni concentration. Nickel in treated drinking water affected A. cepa at the concentration $0.35 \mathrm{mM}\left(\mathrm{EC}_{50}\right)$, showing a strong phytotoxic effect, in agreement with the findings of literature ${ }^{18}$. Moreover, based on $\mathrm{EC}_{50}$ values, nickel concentration in drinking water sample should be decreased by a factor of: 3.9, 2.7, 1.5 and 1.45 to obtain the same root growth inhibition effect corresponding, respectively to: Bahçellek, Zues, O. e Madhe and O. i Vjetër.

\begin{tabular}{cccc}
\multicolumn{4}{c}{ TABLE-3 } \\
OVERVIEW OF EC VALUES WITH A STANDARD \\
DEVIATION 5 \% OR LESS \\
\hline \multirow{3}{*}{ Samples } & \multicolumn{3}{c}{$\mathrm{EC}(\mathrm{mM})$} \\
\cline { 2 - 4 } & $\mathrm{EC}_{70}$ & $\mathrm{EC}_{50}$ & $\mathrm{EC}_{30}$ \\
\hline Dobraç & 0.12 & 0.35 & 2.25 \\
Bahçellek & 0.018 & 0.09 & 1.58 \\
Zues & 0.025 & 0.13 & 1.80 \\
O.Madhe & 0.067 & 0.21 & 1.90 \\
O. Vjetër & 0.058 & 0.24 & 1.88 \\
\hline
\end{tabular}

After 1990' the activity of mines and chemical industry have been minimal in Albania, so closed to the analyzed water bodies there is not present any rather problematic industrial effluents source, except the residues of iron, nickel and chromium mines in the North and North-East Albania, which have negative impact and pose a risk for biota and human health. However the above cited reports revealed that the total quantity of heavy metals and organic pollutants and the bio-availabe fraction of heavy metals $\mathrm{Cr}, \mathrm{Ni}, \mathrm{Fe}, \mathrm{Cu}, \mathrm{Cd}, \mathrm{Zn}$ and $\mathrm{Pb}$ resulted lower than EU admissible limit standards for natural waters ${ }^{19}$. The highest water and sediments concentration of nickel resulted in Bahçellek (Drini river) and as a consequence of natural transport in Zues (Buna river). The results of this paper taken from Allium biotest were in compatibility with above mentioned chemical analyses, concerning Bahçellek and Zues samples. Oblikë e Madhe and Obot i Vjetër samples, despite the possible impact of agricultural practices and 2010 massive flooding, showed a good water quality.

\section{Conclusion}

The present investigation reported for the first time a comparative macroscopic effects on A.cepa roots, grown in some Buna and Drini river water samples enriched with $\mathrm{Ni}\left(\mathrm{NO}_{3}\right)_{2}$ salt, a region with deficiencies in the treatment and disposal of urban-industrial and agriculture wastes. This plant test exhibited different sensitivities, showing some kind of correlation to river water quality through its chemical parameters. The results may be considered as providing a warning or an indicator that the tested natural waters and their natural or anthropogenic nickel enrichment may be a risk to the environment and human health. Due to the fast root growth and quick response to the different tested chemicals, simple experimental and inexpensive work, the Allium test could be useful for a practical water quality assessment and environmental education projects in developing countries as Albania.

\section{REFERENCES}

1. B.A. Zarcinas, C.F. Ishak, M.J. Mclaughlin and G. Cozens, Environ. Geochem. Health, 26, 343 (2004).

2. M.S.A. Ahamd, M. Hussain, R. Saddiq, A. Alvi and K. Mungbean, Bul.. Environ. Contam. Toxicol., 78, 319 (2007).

3. G.C. Panda, S.K. Das, T.S. Bandopadhyay and A.K. Guha, Colloid. Surf. B, 57, 135 (2007).

4. D.F. Easton, J. Peto, L.G. Morgan, L.P. Metcalfe V. Usher and R. Doll, Nickel and Human Health: Current Perspective, John Wiley \& Sons, Toronto, Chap. 46, pp. 603-619 (1992).

5. A.C. Rastall, A. Neziri, Z. Vukoviç, C. Jung, S. Mijoviç, H. Hollert, S. Nikceviç and L. Erdinger, Environ. Sci. Pollut. Res., 11, 240 (2004).

6. O. Royset, B.O. Rosseland, T. Kristensen, F. Kroglund, O.A. Garmo and E. Steinnes, Environ. Sci. Tech., 39, 1167 (2005).

7. H.J. Albering, S.M. van Leusen, E.J.C. Moonen, J.A. Hoogewerff and J.C.S. Kleinjans, Environ. Health Persp., 107, 37 (1999).

8. http://www.miningwatch.ca/index.php?/Newsletter_7/Mining_ Water_Pollution.

9. G. Fiskesjö, Hereditas, 102, 99 (1985).

10. D.M. Leme and M.A. Marin-Morales, Mut. Res./Rev., 682, 71 (2009).

11. http://maps.grida.no/go/graphic/water_quality_in_albania.

12. P.S. Filipoviç and A. Topaloviç, The Shkodra/Skadar Lake Project: Water Quality Assessment, Physical-Chemical Investigations of Skadar Lake. Heidelberg Conference Report, Germany (2002).

13. A. Bekteshi and S. Mijoviç, Bul. Shk., Ser. Shk. Nat., USh., Shkodër, 53, 29 (2003).

14. A. Neziri and W. Gössler, In Proceedings of BALWOIS Conference: Water Observation and Information System for Decision Support, Macedonia (2006).

15. A. Neziri, P. Lazo, J. Brümmer and R. Falcon, In Proceedings of 3rd International Passive Sampling Workshop and Symposium: Passive Sampling of Emerging Pollutants: State of the Art and Perspectives, Czech Republic (2009).

16. D. Kopliku, A. Mesi and S. Golemi, In Proceedings of First International Conference of Agriculture, Food and Environment, Albania, (2011).

17. A. Mesi and D. Kopliku, J. Internat. Environ. Appl. Sci., 6, 654 (2011).

18. H. Akbaç, F. Dane and Ç. Meriç, Indian J. Chem. Biophys., 46, 332 (2009).

19. World Health Organization: Guidelines for Drinking-Water Quality. WHO Library Cataloguing-in-Publication Data, edn. 4 (2011). 